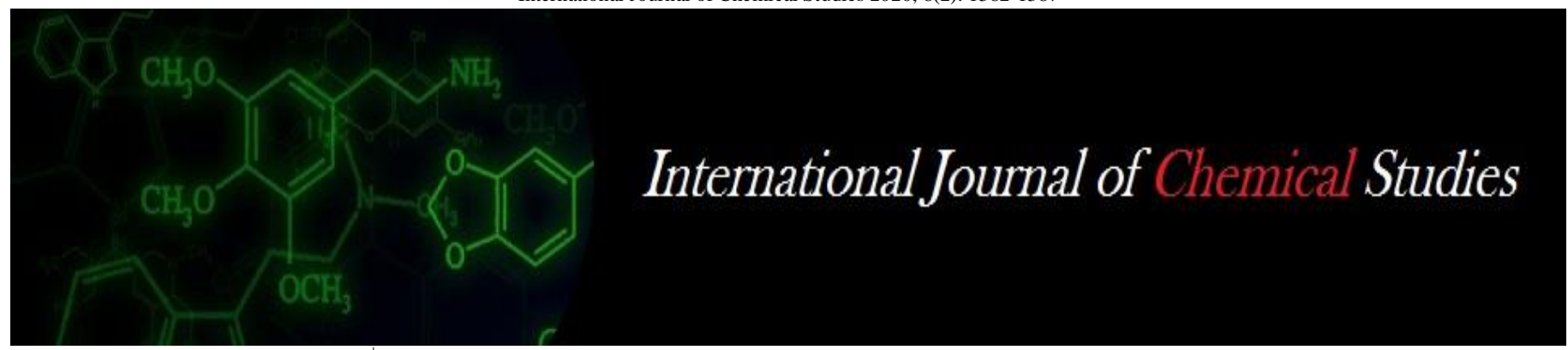

P-ISSN: 2349-8528

E-ISSN: 2321-4902

www.chemijournal.com

IJCS 2020; 8(2): 1382-1387

(C) 2020 IJCS

Received: 18-01-2020

Accepted: 22-02-2020

Pratap Singh Rathiya

IGKV, Potato and Temperate

Fruit Research Station, Mainpat,

Chhattisgarh, India

Rajendra Lakpale

IGKV, DKS College of

Agriculture and Research

Station, Bhatapara,

Chhattisgarh, India

Rupesh Deshmukh

Technical Assistant, Dept. of

Agronomy, IGKV, Raipur,

Chhattisgarh, India
Corresponding Author: Pratap Singh Rathiya

IGKV, Potato and Temperate

Fruit Research Station, Mainpat,

Chhattisgarh, India

\section{Effect of dates of sowing with residual nutrient of preceding crop and direct impact of nutrients at varying levels on yield, nutrient uptake and economics of buckwheat (Fagopyrum esculentum) in northern hills of Chhattisgarh}

\author{
Pratap Singh Rathiya, Rajendra Lakpale and Rupesh Deshmukh
}

DOI: https://doi.org/10.22271/chemi.2020.v8.i2u.8956

\begin{abstract}
A field experiment was conducted in two consecutive rabi 2016-17 and 2017-18, at Mainpat, Chhattisgarh to find out the suitable date of sowing, residual nutrient of preceding crop and direct effect of nutrient at varying levels on succeeding buckwheat for obtaining higher productivity, profitability nutrient uptake and quality of local buckwheat cultivars in hilly area of Chhattisgarh. The experiment was laid out in split-split plot design with three date of sowing viz., $\mathrm{D}_{1}-1^{\text {st }}$ week of October, $\mathrm{D}_{2}-3^{\text {rd }}$ week of October and $\mathrm{D}_{3}-1^{\text {st }}$ week of November as main plot treatments and three residual nutrient effect of preceding crop viz., $\mathrm{F}_{1}-100 \% \mathrm{RDF}, \mathrm{F}_{2}-100 \% \mathrm{RDF}+5 \mathrm{t} \mathrm{FYM} \mathrm{ha}^{-1}$ and $\mathrm{F}_{3}-150 \%$ RDF as sub plot treatments and three direct application of nutrients viz., $\mathrm{F}_{0}-\mathrm{Control,} \mathrm{F}_{1}-50 \%$ RDF and $\mathrm{F}_{2}-100 \%$ RDF on buckwheat, as sub-sub plot treatments. Results revealed that sowing of buckwheat on $1^{\text {st }}$ week of October $\left(D_{1}\right)$, recorded significantly higher plant height $(85.77,86.28 \mathrm{~cm})$, primary branches plant ${ }^{-1}(6.70,6.80)$, dry matter accumulation plant $^{-1}(7.07,7.17 \mathrm{~g})$, number of seeds plant $\mathrm{t}^{-1}(171.19,177.04)$, seed weight $\operatorname{plant}^{-1}(4.19,4.25 \mathrm{~g})$ and 1000 seed weight $(22.53,22.66 \mathrm{~g})$, seed yield $\left(9.41,9.52 \mathrm{q} \mathrm{ha}^{-1}\right)$, NPK uptake by grains, net return ( $₹ 24207,25430 \mathrm{ha}^{-1}$ ) and B:C ratio $(2.80,2.75)$. Higher protein content $(13.07$, $13.32 \%$ ), but no significantly affected by the date of sowing. Among the residual nutrient of preceding crop with $150 \%$ RDF recorded significantly higher all growth characteristics, yield attributes, seed yield, NPK uptakes, protein content, net return and B:C ratio. Irrespective of direct application of nutrients with $100 \%$ RDF recorded significantly higher plant height plant height $(80.33,81.07 \mathrm{~cm})$, primary branches plant $^{-1}(6.73,6.82)$, dry matter accumulation plant ${ }^{-1}(6.91,7.00 \mathrm{~g})$, number of seeds plant ${ }^{-1}(165.46$, 170.06), seed weight plant ${ }^{-1}(4.29,4.34 \mathrm{~g})$ and 1000 seed weight $(22.65,22.69 \mathrm{~g})$, seed yield $(9.02,9.08 \mathrm{q}$ $\left.\mathrm{ha}^{-1}\right)$, NPK uptake by grains, protein content $(13.16,13.44 \%)$ and net return (₹ $\left.21319,22230 \mathrm{ha}^{-1}\right)$, except $\mathrm{B}: \mathrm{C}$ ratio $(2.52,2.46)$, it was recorded under control $\left(\mathrm{F}_{1}\right)$ treatment.
\end{abstract}

Keywords: Cucumber, boron, yield, quality, konkan

\section{Introduction}

Buckwheat is an underutilized (pseudo cereal) crop, important for food security in the temperate and hilly regions of countries (Arora, 1995) ${ }^{[2]}$. It grown as rainfed crop in hilly areas, it cultivated from $600 \mathrm{~m}$ to $>4500 \mathrm{~m}$ altitude level, where no other crops can grow. The area and production of buckwheat, which covered about 20,000 hectares kharif in the hills of India, with total production of 6000 metric tonnes. Buckwheat is a staple food in the high mountains and cultivated specially in hills region of India, spreading from north-west hills of Jammu Kashmir to north eastern region of Arunachal Pradesh. It is also widely grown in Nilgiri hills region of Southern India.

Buckwheat crop is better adapted to low-fertile soils than most other crops and often the residual nutrients from preceding crops are enough for adequate growth (Bjorkman et al., 2008) ${ }^{[3]}$. Buckwheat crop adjusted well as continuously into very tight cropping sequence in the mid hills region and plain region, due to its early duration makes it ideal as relay cropping. It one of the major food crops in higher hilly regions is known as hundred days crop (Dongol, 2001) ${ }^{[5]}$. Buckwheat having potential for fixing atmosphere nitrogen (Alekseyeva, 2002) ${ }^{[1]}$, and thrives well under poor soil fertility conditions. Buckwheat may also play an important 
role in food supply as a contingent crop in aberrant weather situation due to crop failure. It possesses tolerance ability against drought and extreme environment. Herbaceous, fast growing and smothering growth habits it protect from soil erosion and improves soil binding capacity during the high rainfall (Joshi and Paroda, 1991) ${ }^{[11]}$. In Northern hills zone of Chhattisgarh, total area of buckwheat crop about 2000 ha with productivity 12 to $13 \mathrm{q} \mathrm{ha}^{-1}$. The buckwheat crop grown by farmers in the months of September to October with optimum moisture conditions and also can be grown after harvesting of preceding kharif crop due to its better productivity under existing climatic conditions. The multipurpose nutritive value of buckwheat coupled with early duration (80-90 days), lower nutrients rate, low water required with greater ability to adapt well under degraded waste and marginal lands, makes it an more ideal crop in hills region for future sustainable agriculture. Hence, present experiment was conducted to find out suitable dates of sowing with better nutrient management practices for sustaining productivity of buckwheat crop under northern hills zone of Chhattisgarh.

\section{Materials and methods}

The investigation entitled "Effect of different dates of sowing with residual nurient of preceding crop and direct impact of nutrients at varying levels on growth, yield, nutrient uptake and economic of buckwheat (Fagopyrum esculentum)" was conducted during rabi season of 2016-17 and 2017-18 at Instructional Farm of Potato and Temperate Fruit Research Station, IGKV at Mainpat, Chhattisgarh, located between $22^{0} 76^{\prime} \mathrm{N}$ latitude, $83^{0} 31^{\prime} \mathrm{E}$ longitude and $1075 \mathrm{~m}$ altitude, above mean sea level. The soil of the experimental site was sandy clay loam (Inceptisol) in texture with acidic in $\mathrm{pH}$ (6.13) and low organic carbon $(0.45 \%)$. The physico-chemical analysis of the soil was done by collecting soil samples from a depth of 0 to $15 \mathrm{~cm}$. The soil contained low nitrogen $(215.0$ $\left.\mathrm{kg} \mathrm{ha}^{-1}\right)$, medium in available phosphorus $\left(15.14 \mathrm{~kg} \mathrm{ha}^{-1}\right)$ and high potassium $\left(278.0 \mathrm{~kg} \mathrm{ha}^{-1}\right)$ respectively. The experiment was conducted in split-split plot design, replicated thrice, with three dates of sowing viz., $\mathrm{D}_{1}-1^{\text {st }}$ week of October, $\mathrm{D}_{2-} 3^{\text {rd }}$ week of October and $\mathrm{D}_{3}-1^{\text {st }}$ week of November in the main plot treatments with three residual nutrient effect of preceding crop viz., $\mathrm{F}_{1}-100 \% \mathrm{RDF}, \mathrm{F}_{2}-100 \% \mathrm{RDF}+5 \mathrm{t} \mathrm{FYM} \mathrm{ha}^{-1}$ and $\mathrm{F}_{3}-150 \% \mathrm{RDF}$ as sub plot treatments and three levels of direct nutrients application viz., $\mathrm{F}_{0}$-control, $\mathrm{F}_{1}-50 \% \mathrm{RDF}$ and $\mathrm{F}_{2}-$ $100 \%$ RDF (40:30:20 kg NPK ha ${ }^{-1}$ ) on buckwheat, as sub-sub plot treatments of $4.5 \times 4.5 \mathrm{~m}$ size. Basal dose of half of $\mathrm{N}$, full $\mathrm{P}$ and $\mathrm{K}$ were applied through urea, single super phosphate and muriate of potash respectively and rest of half of $\mathrm{N}$ was top dressed at 40 days after sowing during both years experiment. Sowing of buckwheat was done after harvesting of preceding crop on $1^{\text {st }}$ week of October, $3^{\text {rd }}$ week of October and $1^{\text {st }}$ week of November apart of $30 \mathrm{~cm}$ row to row in rabi season under rainfed conditions. The rainfall received during the crop growth period was $79.80 \mathrm{~mm}$ and $30.20 \mathrm{~mm}$ in first and second year, respectively. Plant sample of seed and straw of buckwheat collected at harvest of crop and thus were grinded with the help of willey grinding mill and passed through $0.5 \mathrm{~mm}$ mesh sieve. $\mathrm{N}, \mathrm{P}$ and $\mathrm{K}$ content from seed and straw were estimated using standard procedures given by Jackson (1967) ${ }^{[10]}$. N, P and K uptake were computed by multiplying their respective content in the dry matter of plant and yield data. Protein content of grain was computed for treatments by multiplying nitrogen content with the conversion factor of 6.25 . The data on various variables were analysed by using statistical procedures as described by Gomez and Gomez (1984) ${ }^{[8]}$.

\section{Results and discussion \\ Growth parameters}

Plant growth parameters viz., plant height, number of primary branches plant ${ }^{-1}$ and dry matter accumulation plant ${ }^{-1}$ at harvest stage was significantly affected by date of sowing, residual nutrient effect of preceding crop and direct effect of nutrient on succeeding buckwheat during both the years experiment (Table 1). Sowing of buckwheat crop on $1^{\text {st }}$ week of October $\left(D_{1}\right)$ recorded significantly taller plant height $(85.77,86.28$ $\mathrm{cm})$, number of primary branches plant ${ }^{-1}(6.70,6.80)$ and dry matter accumulation plant $^{-1}(7.07,7.17 \mathrm{~g})$ as compared to other treatments during both years of experiment. It might be due to the availability of sufficient growth resources i.e. moisture, nutrients and solar radiation, which are at the disposal of buckwheat. Late-sown buckwheat germinated late and grows slowly during early growth period due to low temperature and therefore, less plant height, branches and dry matter accumulation than early-sown crop. Similar findings also observed by Patel, et al., (1999) ${ }^{[15]}$. The shortest plant height, low primary branches plant ${ }^{-1}$ and dry matter accumulation plant $^{-1}$ of buckwheat recorded when crop sown on $1^{\text {st }}$ week of November $\left(D_{3}\right)$ during both years of experiment. Saini et al. (1986) ${ }^{[17]}$ reported that decrease in different vegetative growth stages with late sowing. Nutrient availability is reduced under delay sowing due to water stressed conditions and high temperature stress affects the photosynthesis process adversely which further lead to low DMA (Wang et al., 2008 and Farre and Faci, 2006) ${ }^{[20,6] .}$ With respect to residual nutrient effect of preceding crop on buckwheat, application of $150 \%$ RDF $\left(\mathrm{F}_{3}\right)$ recorded significantly taller plants $(78.92,79.42 \mathrm{~cm})$, number of primary branches plant ${ }^{-1}(6.45,6.65)$ and dry matter accumulation plant $^{-1}(6.75,6.88 \mathrm{~g})$ as compared to other treatments during both years. It is due to availability of sufficient residual nutrient to buckwheat crop which may produce higher growth parameters. The lower plant growth parameters was observed with application of $100 \% \mathrm{RDF}\left(\mathrm{F}_{1}\right)$, but it was found at par with $100 \% \mathrm{RDF}+5 \mathrm{t} \mathrm{FYM} \mathrm{ha}^{-1}\left(\mathrm{~F}_{2}\right)$ during both years. Among the direct effect of nutrient in buckwheat, application of $100 \%$ RDF $\left(\mathrm{F}_{2}\right)$ recorded significantly taller plant $(80.33,81.07 \mathrm{~cm})$, primary branches plant $^{-1}(6.73,6.82)$, dry matter accumulation plant $^{-1}$ (6.91, $7.00 \mathrm{~g}$ ) as compared to other nutrient levels. The lower plant growth parameters were noticed by control during both years of experiment. The increasing trend in morphological parameters might be due to recommended dose of fertilizers could be attributed to the quick and ready availability of major nutrients like $\mathrm{N}, \mathrm{P}$ and $\mathrm{K}$ to plants at earliar stages of plant growth. These results confirm with the findings of Rana et al. (2005) ${ }^{[16]}$ and Campbell and Gubbels (1978) ${ }^{[4]}$. Snezana et al. (2012) ${ }^{[18]}$ reported that nitrogen helps in synthesis of tryptophan which is a precursor of auxins. The auxins might have hastened the metabolic activities in the plants which in turn increased the vegetative structures and leaves per plant. Li, et al. (2004) [13] reported that after applying fertilizer, the growth, including height of plant, number of branch, inflorescence numbers and biomass was increased. 
Table 1: Plant growth parameters of buckwheat as influenced by sowing time, residual effect of preceding crop and nutrient management in succeeding crop

\begin{tabular}{|c|c|c|c|c|c|c|}
\hline \multirow{2}{*}{ Treatments } & \multicolumn{2}{|c|}{\begin{tabular}{|l|} 
Plant height $(\mathrm{cm})$ \\
\end{tabular}} & \multicolumn{2}{|c|}{ Number of primary branches plant ${ }^{-1}$} & \multicolumn{2}{|c|}{ Dry matter accumulation plant ${ }^{-1}(\mathrm{~g})$} \\
\hline & 2016-17 & 2017-18 & 2016-17 & $2017-18$ & 2016-17 & $2017-18$ \\
\hline \multicolumn{7}{|c|}{ Date of sowing } \\
\hline $\mathrm{D}_{1-1}{ }^{\text {st }}$ week October & 85.77 & 86.28 & 6.70 & 6.80 & 7.07 & 7.17 \\
\hline $\mathrm{D}_{2}-2^{\text {nd }}$ week October & 78.43 & 79.25 & 6.26 & 6.43 & 6.53 & 6.67 \\
\hline $\mathrm{D}_{3}-1^{\text {st }}$ week November & 66.62 & 67.44 & 5.70 & 5.91 & 5.97 & 6.10 \\
\hline SEm \pm & 0.99 & 0.60 & 0.09 & 0.08 & 0.04 & 0.05 \\
\hline $\mathrm{CD}(\mathbf{P}=\mathbf{0 . 0 5})$ & 3.88 & 2.35 & 0.34 & 0.29 & $\mathbf{0 . 1 7}$ & $\mathbf{0 . 2 0}$ \\
\hline \multicolumn{7}{|c|}{ Residual effect of preceding crop } \\
\hline $\mathrm{F}_{1}-100 \% \mathrm{RDF}$ & 75.32 & 76.43 & 6.08 & 6.18 & 6.35 & 6.46 \\
\hline $\mathrm{F}_{2}-100 \% \mathrm{RDF}+5 \mathrm{t} \mathrm{FYM} \mathrm{ha}^{-1}$ & 76.59 & 77.12 & 6.12 & 6.31 & 6.47 & 6.59 \\
\hline $\mathrm{F}_{3}-150 \% \mathrm{RDF}$ & 78.92 & 79.42 & 6.45 & 6.65 & 6.75 & 6.88 \\
\hline SEm \pm & 0.63 & 0.65 & 0.07 & $\mathbf{0 . 1 0}$ & 0.04 & 0.05 \\
\hline $\mathrm{CD}(\mathrm{P}=\mathbf{0 . 0 5})$ & 1.95 & 1.99 & $\mathbf{0 . 2 2}$ & 0.31 & $\mathbf{0 . 1 2}$ & $\mathbf{0 . 1 5}$ \\
\hline \multicolumn{7}{|c|}{ Nutrient management in succeeding crop } \\
\hline $\mathrm{F}_{0}$-Control & 73.70 & 74.67 & 5.77 & 5.93 & 6.11 & 6.29 \\
\hline $\mathrm{F}_{1}-50 \% \mathrm{RDF}$ & 76.79 & 77.22 & 6.16 & 6.40 & 6.56 & 6.64 \\
\hline $\mathrm{F}_{2}-100 \% \mathrm{RDF}$ & 80.33 & 81.07 & 6.73 & 6.82 & 6.91 & 7.00 \\
\hline SEm \pm & 0.55 & 0.69 & 0.09 & 0.10 & 0.07 & 0.06 \\
\hline $\mathrm{CD}(\mathrm{P}=\mathbf{0 . 0 5})$ & 1.57 & 1.97 & 0.26 & 0.27 & 0.19 & 0.18 \\
\hline
\end{tabular}

\section{Yield attributes and yield}

Data presented in Table 2, revealed that seeds plant ${ }^{-1}$, seed weight plant ${ }^{-1}, 1000$ seed weight, seed yield and straw yield as significantly influenced by date of sowing, residual nutrient effect of preceding crop and direct nutrient in succeeding buckwheat. Sowing of buckwheat on $1^{\text {st }}$ week of October $\left(D_{1}\right)$ was recorded significantly maximum number of seeds plant ${ }^{-1}$ $(171.19,177.04)$, seed weight plant ${ }^{-1}(4.19,4.25 \mathrm{~g})$ and 1000 seed weight $(22.53,22.66 \mathrm{~g})$, seed yield $\left(9.41,9.52 \mathrm{q} \mathrm{ha}^{-1}\right)$,) and straw yield $\left(20.29,20.36 \mathrm{q} \mathrm{ha}^{-1}\right)$ compared to rest of treatments during both the years of experiment. This might be due to adequate soil moisture appears at sowing time to be essential for higher seeds plant ${ }^{-1}$, seed weight plant ${ }^{-1}$ and 1000 seed weight yields. Gubbels (1978) ${ }^{[9]}$ reported that the yield of common buckwheat increased with high soil moisture although seed set remained essentially the same. The minimum seeds plant ${ }^{-1}$, seed weight plant ${ }^{-1}(\mathrm{~g})$ and 1000 seed weight $(\mathrm{g})$ was recorded when crop sown $1^{\text {st }}$ week of November $\left(D_{3}\right)$ during both years of experiment. Common buckwheat wilts badly and grows very slowly when affected by low soil moisture. Yoon, et al. (2004) ${ }^{[21]}$ also reported that grain yield was reduced by water deficit as well as water flooding at sowing time. Krotov (1963) ${ }^{[12]}$ reported that flowering at temperature above $30^{\circ} \mathrm{C}$ is accompanied by desiccation of fruit and lowering of yield. Sharp decrease in grain yield with delay sowing was mainly due to significant reduction in grain plant ${ }^{-1}$ and test weight. Among the residual effect of nutrient of preceding crop with $150 \% \operatorname{RDF}\left(\mathrm{F}_{3}\right)$ was recorded significantly highest on number of seeds plant ${ }^{-1}$, seed weight plant ${ }^{-1}, 1000$ seed weight, seed yield and straw yield of buckwheat was than other treatments during both years of experiment. It may be due to the residual of the nutrients applied during the kharif crop, which improved crop growth and thus ultimately higher seeds plant ${ }^{-1}$, seed weight plant $^{-1}$ and 1000 seed weight in buckwheat. Gosh et al. (2009) ${ }^{[7]}$ reported that residual nutrient had positive effect on the yield of succeeding crop registered maximum seed yield. The minimum seeds plant ${ }^{-1}$, seed weight plant ${ }^{-1}$ and 1000 seed weight, seed yield and straw yield was recorded in $100 \% \mathrm{RDF}$ $\left(\mathrm{F}_{1}\right)$, but it was found at par with $100 \% \mathrm{RDF}+5 \mathrm{t} \mathrm{FYM} \mathrm{ha}^{-1}$ $\left(\mathrm{F}_{2}\right)$ during both years of experiment. Direct effect of nutrient on succeeding buckwheat with application of $100 \% \mathrm{RDF}\left(\mathrm{F}_{2}\right)$ produced significantly higher number of seeds plant ${ }^{-1}(165.46$, 170.06), seed weight plant $^{-1}(4.29,4.34 \mathrm{~g})$ and 1000 seed weight $(22.65,22.69 \mathrm{~g})$, seed yield $\left(9.02,9.08 \mathrm{q} \mathrm{ha}^{-1}\right)$ and straw yield $\left(19.31,19.51 \mathrm{q} \mathrm{ha}^{-1}\right)$ than other nutrient levels treatments during both years of experiment. It might be due to direct applied of recommended fertilizers could be attributed to the quickly and ready availability of nutrients to plants for growth and development. $\mathrm{Li}$, et al. (2004) ${ }^{[13]}$ reported that number of grain per plant and grain weight per plant was greatly responded to fertilizer application in buckwheat. Noworolink (1995) ${ }^{[14]}$ stated that the increase in nitrogen can enhance biomass, leaf area, number of branches and quantitative and qualitative grain yields. The minimum yield attributing characters and yield was noted under control $\left(\mathrm{F}_{1}\right)$ during both years of experiment.

Table 2: Yield attributes and yield of buckwheat as influenced by sowing time, residual effect of preceding crop and nutrient management in succeeding crop

\begin{tabular}{|c|c|c|c|c|c|c|c|c|c|c|}
\hline \multirow[t]{2}{*}{ Treatments } & \multicolumn{2}{|c|}{ Number of seeds plant ${ }^{-1}$} & \multicolumn{2}{|c|}{ Seed weight plant ${ }^{-1}(g)$} & \multicolumn{2}{|c|}{ 1000-seed weight $(\mathrm{g})$} & \multicolumn{2}{|c|}{$\begin{array}{c}\text { Seed yield } \\
\left(\mathrm{q} \mathrm{ha}^{-1}\right)\end{array}$} & \multicolumn{2}{|c|}{\begin{tabular}{|c|}
$\begin{array}{c}\text { Stover yield } \\
\left(\mathbf{q} \mathbf{h a}^{-1}\right)\end{array}$ \\
\end{tabular}} \\
\hline & 2016-17 & 2017-18 & 2016-17 & 2017-18 & 2016-17 & 2017-18 & 2016-17 & 2017-18 & 2016-17 & 2017-18 \\
\hline \multicolumn{11}{|c|}{ Date of sowing } \\
\hline$D_{1}-1^{\text {st }}$ week October & 171.19 & 177.04 & 4.19 & 4.25 & 22.53 & 22.66 & 9.41 & 9.52 & 20.29 & 20.36 \\
\hline $\mathrm{D}_{2}-2^{\text {nd }}$ week October & 154.30 & 157.76 & 3.88 & 3.94 & 22.03 & 22.11 & 8.35 & 8.43 & 18.70 & 18.87 \\
\hline $\mathrm{D}_{3}-1^{\text {st }}$ week November & 133.98 & 136.51 & 3.36 & 3.48 & 21.51 & 21.61 & 6.84 & 6.90 & 16.08 & 16.18 \\
\hline SEm \pm & 1.58 & 1.53 & 0.06 & 0.04 & 0.09 & 0.13 & 0.11 & 0.07 & 0.18 & 0.15 \\
\hline $\mathrm{CD}(\mathrm{P}=\mathbf{0 . 0 5})$ & 6.22 & 6.01 & 0.24 & 0.16 & 0.36 & 0.51 & 0.44 & 0.26 & 0.69 & 0.57 \\
\hline \multicolumn{11}{|c|}{ Residual effect of preceding crop } \\
\hline $\mathrm{F}_{1}-100 \% \mathrm{RDF}$ & 146.45 & 150.28 & 3.54 & 3.66 & 21.74 & 21.81 & 7.78 & 7.87 & 17.82 & 17.93 \\
\hline
\end{tabular}




\begin{tabular}{|c|c|c|c|c|c|c|c|c|c|c|}
\hline $\mathrm{F}_{2}-100 \% \mathrm{RDF}+5 \mathrm{t} \mathrm{FYM} \mathrm{ha} \mathrm{ha}^{-1}$ & 150.67 & 153.69 & 3.66 & 3.77 & 21.95 & 22.03 & 7.94 & 7.98 & 18.07 & 18.09 \\
\hline $\mathrm{F}_{3}-150 \% \mathrm{RDF}$ & 162.36 & 167.33 & 4.24 & 4.25 & 22.38 & 22.54 & 8.88 & 8.99 & 19.19 & 19.38 \\
\hline SEm + & 1.50 & 1.11 & 0.08 & 0.06 & 0.11 & 0.08 & 0.10 & 0.09 & 0.18 & 0.16 \\
\hline $\mathrm{CD}(\mathrm{P}=\mathbf{0 . 0 5})$ & 4.61 & 3.41 & 0.26 & 0.18 & $\mathbf{0 . 3 3}$ & 0.24 & 0.31 & $\mathbf{0 . 3 0}$ & $\mathbf{0 . 5 5}$ & 0.49 \\
\hline \multicolumn{11}{|c|}{ Nutrient management in succeeding crop } \\
\hline $\mathrm{F}_{0}$-Control & 141.46 & 144.08 & 3.43 & 3.55 & 21.42 & 21.54 & 7.54 & 7.62 & 17.42 & 17.49 \\
\hline $\mathrm{F}_{1}-50 \% \mathrm{RDF}$ & 152.56 & 157.17 & 3.71 & 3.79 & 21.99 & 22.15 & 8.05 & 8.15 & 18.34 & 18.40 \\
\hline $\mathrm{F}_{2}-100 \% \mathrm{RDF}$ & 165.46 & 170.06 & 4.29 & 4.34 & 22.65 & 22.69 & 9.02 & 9.08 & 19.31 & 19.51 \\
\hline SEm \pm & 1.07 & 1.13 & 0.04 & 0.05 & 0.12 & 0.10 & 0.07 & 0.06 & 0.11 & 0.12 \\
\hline $\mathrm{CD}(\mathrm{P}=\mathbf{0 . 0 5})$ & 3.06 & 3.24 & 0.13 & 0.16 & 0.35 & 0.28 & 0.20 & 0.18 & 0.32 & $\mathbf{0 . 3 3}$ \\
\hline
\end{tabular}

\section{Interaction effect on yield}

Date of sowing $\mathrm{x}$ direct effect of nutrient and residual effect of nutrient $\mathrm{x}$ direct effect of nutrient was recorded significant variation on grain yield of buckwheat (Table 3). Sowing of buckwheat $\left(D_{1}\right)$ after harvest of preceding kharif crop gave significantly more yield with application $100 \%$ RDF in succeeding buckwheat crop (10.52 $\left.\mathrm{q} \mathrm{ha}^{-1}\right)$ and residual effect of nutrient at $150 \%$ RDF of preceding crop to buckwheat recorded significantly higher yield $\left(10.21 \mathrm{q} \mathrm{ha}^{-1}\right)$ than rest of the treatments on mean data. Minimum grain yield was recorded in delay sowing of buckwheat $\left(D_{3}\right)$ at without fertilizer application (control) to buckwheat and 100\% RDF of residual nutrient of preceding crop.

Table 3: Interaction of seed yield as influenced by sowing time, residual effect of preceding crop and nutrient management in succeeding crop

\begin{tabular}{|c|c|c|c|}
\hline \multirow{2}{*}{ Treatments } & \multicolumn{3}{|c|}{ Nutrient management in succeeding crop } \\
\hline & $\mathrm{F}_{0}$-Control & $\mathrm{F}_{1-50 \%} \mathrm{RDF}$ & $\mathrm{F}_{2}-100 \% \mathrm{RDF}$ \\
\hline \multicolumn{4}{|l|}{ Date of sowing } \\
\hline $\mathrm{D}_{1}-1^{\text {st }}$ week October & 8.59 & 9.29 & 10.52 \\
\hline $\mathrm{D}_{2}-3^{\text {rd }}$ week October & 7.95 & 8.27 & 8.96 \\
\hline $\mathrm{D}_{3}-1^{\text {st }}$ week November & 6.19 & 6.74 & 7.67 \\
\hline SEm \pm & \multirow{2}{*}{\multicolumn{3}{|c|}{$\begin{array}{l}0.08 \\
0.23 \\
\end{array}$}} \\
\hline $\mathrm{CD}(\mathbf{P}=0.05)$ & & & \\
\hline \multicolumn{4}{|c|}{ Residual effect of preceding crop } \\
\hline $\mathrm{F}_{1}-100 \% \mathrm{RDF}$ & 7.26 & 7.69 & 8.53 \\
\hline $\mathrm{F}_{2}-100 \% \mathrm{RDF}+5 \mathrm{t} \mathrm{FYM} \mathrm{ha}^{-1}$ & 7.58 & 7.89 & 8.41 \\
\hline $\mathrm{F}_{3}-150 \% \mathrm{RDF}$ & 7.90 & 8.71 & 10.21 \\
\hline SEm + & \multirow{2}{*}{\multicolumn{3}{|c|}{$\begin{array}{l}0.08 \\
0.23\end{array}$}} \\
\hline $\mathrm{CD}(\mathrm{P}=\mathbf{0 . 0 5})$ & & & \\
\hline
\end{tabular}

\section{Nutrient uptake}

Nutrient uptake by grains and protein content as influenced by date of sowing, residual nutrient effect and direct effect of nutrient in succeeding crop (Table 4). Among date of sowing, significantly higher NPK uptake by grains were recorded when buckwheat sown on $1^{\text {st }}$ week of October $\left(D_{1}\right)$ followed by $3^{\text {rd }}$ week of October $\left(D_{2}\right)$ during both years of experiment. The minimum N, P and $\mathrm{K}$ uptake by grains were observed when crop sown on $1^{\text {st }}$ week of November $\left(D_{3}\right)$. This might be due higher seed yield and nitrogen, phosphorus and potassium content under timely sowing of buckwheat. Patel et al., (1999) ${ }^{[15]}$ also reported that nutrient content in seeds and stover and uptake have negative response with delay in crop sowing and higher temperature during the crop growth. With regard to residual nutrient effect of preceding crop, significantly higher $\mathrm{N}, \mathrm{P}$ and $\mathrm{K}$ uptake by grain were recorded with application of $150 \% \operatorname{RDF}\left(\mathrm{F}_{3}\right)$ than others during both years of experiment. With respect to nutrient management in succeeding crop, significantly higher $\mathrm{N}, \mathrm{P}$ and $\mathrm{K}$ uptake by grains were noticed with application of $100 \%$ RDF $\left(\mathrm{F}_{2}\right)$ during both years of experiment. The lowest $\mathrm{N}, \mathrm{P}$ and $\mathrm{K}$ uptake by grains were recorded in control $\left(\mathrm{F}_{0}\right)$. It is due to attributed to addition of various nutrients levels enhanced the $\mathrm{N}, \mathrm{P}$ and $\mathrm{K}$ concentration in grain of the crops by sufficient nutritional environment and greater photosynthetic efficiency, which ultimately favoured maximum growth and crop yield.

Table 4: NPK uptake and protein content of buckwheat grains as influenced by sowing time, residual effect of preceding crop and nutrient management in succeeding crop

\begin{tabular}{|c|c|c|c|c|c|c|c|c|}
\hline \multirow{3}{*}{ Treatments } & \multicolumn{6}{|c|}{ Nutrient uptake $\left(\mathrm{kg} \mathrm{ha}^{-1}\right)$ by buckwheat grains } & \multirow{2}{*}{\multicolumn{2}{|c|}{ Protein content $(\%)$}} \\
\hline & \multicolumn{2}{|c|}{$\mathbf{N}$} & \multicolumn{2}{|c|}{$\mathbf{P}$} & \multicolumn{2}{|c|}{$\mathbf{K}$} & & \\
\hline & 2016-17 & 2017-18 & 2016-17 & 2017-18 & 2016-17 & 2017-18 & 2016-17 & 2017-18 \\
\hline \multicolumn{9}{|c|}{ Date of sowing } \\
\hline $\mathrm{D}_{1}-1^{\mathrm{st}}$ week October & 19.68 & 20.31 & 3.89 & 4.12 & 7.01 & 7.27 & 13.07 & 13.32 \\
\hline $\mathrm{D}_{2}-2^{\text {nd }}$ week October & 17.16 & 17.61 & 3.28 & 3.61 & 5.96 & 6.24 & 12.81 & 13.02 \\
\hline $\mathrm{D}_{3}-1^{\text {st }}$ week November & 13.82 & 14.28 & 2.63 & 2.81 & 4.78 & 5.00 & 12.58 & 12.88 \\
\hline SEm \pm & 0.22 & 0.26 & 0.08 & $\mathbf{0 . 0 7}$ & $\mathbf{0 . 1 0}$ & 0.07 & 0.16 & 0.13 \\
\hline $\mathrm{CD}(\mathrm{P}=\mathbf{0 . 0 5})$ & $\mathbf{0 . 8 8}$ & 1.04 & $\mathbf{0 . 3 3}$ & 0.29 & $\mathbf{0 . 3 9}$ & 0.26 & NS & NS \\
\hline \multicolumn{9}{|c|}{ Residual effect of preceding crop } \\
\hline $\mathrm{F}_{1-100 \% \mathrm{RDF}}$ & 15.79 & 16.22 & 2.77 & 3.01 & 5.29 & 5.58 & 12.63 & 12.84 \\
\hline $\mathrm{F}_{2}-100 \% \mathrm{RDF}+5 \mathrm{t} \mathrm{FYM} \mathrm{ha}^{-1}$ & 16.16 & 16.68 & 2.91 & 3.29 & 5.57 & 5.78 & 12.70 & 13.01 \\
\hline $\mathrm{F}_{3}-150 \% \mathrm{RDF}$ & 18.72 & 19.30 & 4.11 & 4.24 & 6.89 & 7.15 & 13.12 & 13.36 \\
\hline SEm \pm & 0.25 & 0.25 & 0.07 & 0.09 & 0.09 & 0.12 & 0.10 & 0.12 \\
\hline $\mathrm{CD}(\mathrm{P}=\mathbf{0 . 0 5})$ & 0.76 & 0.78 & 0.22 & 0.28 & 0.29 & 0.37 & 0.30 & 0.38 \\
\hline
\end{tabular}




\begin{tabular}{|c|c|c|c|c|c|c|c|c|}
\hline \multicolumn{9}{|c|}{ Nutrient management in succeeding crop } \\
\hline$F_{0}$-Control & 15.12 & 15.56 & 2.57 & 2.71 & 4.92 & 5.24 & 12.51 & 12.73 \\
\hline $\mathrm{F}_{1}-50 \%$ RDF & 16.47 & 17.04 & 3.00 & 3.44 & 5.85 & 6.03 & 12.78 & 13.05 \\
\hline $\mathrm{F}_{2}-100 \%$ RDF & 19.07 & 19.60 & 4.22 & 4.39 & 6.99 & 7.24 & 13.16 & 13.44 \\
\hline SEm \pm & $\mathbf{0 . 1 7}$ & $\mathbf{0 . 1 7}$ & $\mathbf{0 . 0 7}$ & $\mathbf{0 . 0 6}$ & $\mathbf{0 . 0 7}$ & $\mathbf{0 . 0 7}$ & $\mathbf{0 . 0 8}$ & $\mathbf{0 . 0 8}$ \\
\hline CD $(\mathbf{P}=\mathbf{0 . 0 5})$ & $\mathbf{0 . 4 8}$ & $\mathbf{0 . 4 9}$ & $\mathbf{0 . 2 1}$ & $\mathbf{0 . 1 6}$ & $\mathbf{0 . 2 0}$ & $\mathbf{0 . 2 1}$ & $\mathbf{0 . 2 4}$ & $\mathbf{0 . 2 4}$ \\
\hline
\end{tabular}

\section{Protein content (\%)}

Protein content in buckwheat grain was unaffected by date of sowing during both the years of experiment (Table 4). With respect to residual effect of nutrient of preceding crop, significantly higher protein content $(13.12,13.36 \%)$ of buckwheat grain was found with residual of $150 \% \operatorname{RDF}\left(\mathrm{F}_{3}\right)$ than other treatments during both years experiment. Among the direct effect of nutrient in buckwheat, significantly higher protein content $(13.16,13.44 \%)$ of buckwheat grain were noticed with $100 \%$ RDF $\left(\mathrm{F}_{2}\right)$ during both years of experiment. The lowest protein content and protein yield in buckwheat grain was found in control $\left(\mathrm{F}_{0}\right)$. Protein content showed an increasing trend with increasing fertility level. The similar findings also noticed by Sobhani et al. (2014) ${ }^{[19]}$.

\section{Economics}

Net return and B:C ratio of buckwheat as affected by date of sowing, residual nutrient effect and direct effect of nutrient on succeeding crop (Table 5). With respect to date of sowing, maximum net return ( $₹ 24207,25430 \mathrm{ha}^{-1}$ ) and B:C ratio $(2.80,2.75)$ were obtained when crop sown on $1^{\text {st }}$ week of October $\left(D_{1}\right)$ compared to rest of treatments during both years of experiment. The minimum net return and $\mathrm{B}: \mathrm{C}$ ratio were obtained when crop sown on $1^{\text {st }}$ week of November $\left(D_{3}\right)$. It is due to better expression of yield components of timely sowing crop that ultimately recorded higher production potential accompanied with good monetary return. Among the residual nutrient effect of preceding crop, higher net return (₹ 22109, $\left.23219 \mathrm{ha}^{-1}\right)$ and $\mathrm{B}: \mathrm{C}$ ratio $(2.64,2.59)$ were obtained with application of $150 \% \mathrm{RDF}\left(\mathrm{F}_{3}\right)$ than other treatments during both years of experiment. The lowest net return and $\mathrm{B}: \mathrm{C}$ ratio was recorded with $100 \% \mathrm{RDF}\left(\mathrm{F}_{1}\right)$, but it was found at par with $100 \% \mathrm{RDF}+5 \mathrm{t} \mathrm{FYM} \mathrm{ha}{ }^{-1}\left(\mathrm{~F}_{2}\right)$ during both years of experiment. This was owing to highly increase in grain yield of buckwheat due to positive effect of residual nutrient of preceding crop. Direct effect of nutrient on succeeding crop, higher net return ( $₹ 21319,22230$ ha $^{-1}$ ) was obtained with $100 \% \mathrm{RDF}\left(\mathrm{F}_{2}\right)$ compared to rest of treatments, but maximum value of $\mathrm{B}: \mathrm{C}$ ratio was obtained with control $\left(\mathrm{F}_{0}\right)$ during both years of experiment. This might be due to the increasing in nutrient availability, which recorded in higher grain yield and better market price without proportionate increase in cost of cultivation. Higher economic returns due to balance fertilization in buckwheat were also reported by Rana et al. (2005) ${ }^{[16]}$. Maximum benefit cost ratio under control was due to lowering cost of cultivation.

Table 5: Economics in buckwheat crop as influenced by sowing time, residual effect of preceding crop and nutrient management in succeeding crop

\begin{tabular}{|c|c|c|c|c|c|c|}
\hline \multirow{2}{*}{ Treatments } & \multicolumn{2}{|c|}{ Cost of cultivation ( $₹$ ha $^{-1}$ ) } & \multicolumn{2}{|c|}{ Net return ( $₹$ ha $\left.^{-1}\right)$} & \multicolumn{2}{|c|}{ B:C ratio } \\
\hline & 2016-17 & 2017-18 & 2016-17 & 2017-18 & 2016-17 & 2017-18 \\
\hline \multicolumn{7}{|c|}{ Date of sowing } \\
\hline$D_{1}-1^{\text {st }}$ week October & 13430 & 14557 & 24207 & 25430 & 2.80 & 2.75 \\
\hline $\mathrm{D}_{2}-2^{\text {nd }}$ week October & 13430 & 14557 & 19986 & 20844 & 2.50 & 2.44 \\
\hline $\mathrm{D}_{3}-1^{\text {st }}$ week November & 13430 & 14557 & 13930 & 14410 & 2.04 & 1.99 \\
\hline SEm \pm & - & - & 452 & 278 & $\mathbf{0 . 0 3}$ & $\mathbf{0 . 0 2}$ \\
\hline $\mathrm{CD}(\mathbf{P}=\mathbf{0 . 0 5})$ & - & - & 1775 & 1090 & 0.14 & 0.08 \\
\hline \multicolumn{7}{|c|}{ Residual effect of preceding crop } \\
\hline $\mathrm{F}_{1-100 \% \mathrm{RDF}}$ & 13430 & 14557 & 17694 & 18494 & 2.32 & 2.27 \\
\hline $\mathrm{F}_{2}-100 \% \mathrm{RDF}+5 \mathrm{t} \mathrm{FYM} \mathrm{ha}^{-1}$ & 13430 & 14557 & 18319 & 18971 & 2.37 & 2.31 \\
\hline $\mathrm{F}_{3}-150 \% \mathrm{RDF}$ & 13430 & 14557 & 22109 & 23219 & 2.64 & 2.59 \\
\hline SEm \pm & - & - & 406 & 412 & $\mathbf{0 . 0 3}$ & $\mathbf{0 . 0 3}$ \\
\hline $\mathrm{CD}(\mathbf{P}=\mathbf{0 . 0 5})$ & - & - & 1251 & 1268 & 0.09 & $\mathbf{0 . 0 8}$ \\
\hline \multicolumn{7}{|c|}{ Nutrient management in succeeding crop } \\
\hline $\mathrm{F}_{0}$-Control & 11949 & 13016 & 18212 & 18989 & 2.52 & 2.46 \\
\hline $\mathrm{F}_{1}-50 \% \mathrm{RDF}$ & 13595 & 14752 & 18591 & 19465 & 2.37 & 2.32 \\
\hline $\mathrm{F}_{2}-100 \% \mathrm{RDF}$ & 14746 & 15903 & 21319 & 22230 & 2.45 & 2.40 \\
\hline SEm \pm & - & - & 274 & 267 & $\mathbf{0 . 0 2}$ & $\mathbf{0 . 0 2}$ \\
\hline $\mathrm{CD}(\mathbf{P}=\mathbf{0 . 0 5})$ & - & - & 787 & 767 & $\mathbf{0 . 0 6}$ & $\mathbf{0 . 0 5}$ \\
\hline
\end{tabular}

2016-17 2017-18, Market price of buckwheat (₹ q $\left.{ }^{1}\right): 40004200$

\section{References}

1. Alekseyeva ES. Progress and prospects of buckwheat improvement in Ukraine- current status and future research. Fagopyrum. 2002; 19:111-113.

2. Arora RK. Buckwheat genetic resources in the Himalayas their diversity, conservation and use. In: Current Advances in Buckwheat Research. Proc. 6 ${ }^{\text {th }}$ Int. Symp. On Buckwheat in Shinshu 24-29 August 1995 (T. Matano and A. Ujihara, eds.). Shinshu University Press, Asahi Matsumoto. 1995; 1-3:39-46.
3. Bjorkman T, Bellinder R, Hahn R, Shail JW. Buckwheat cover crop hand book Available at, 2008.

http://www.hort.cornell.edu/bjorkman/lab/covercrops/pdf /bwbrochure.pdh (accessed 7 Aug 2014). Cornell University Cooperative Extension, Geneva, NY.

4. Campbell CG, Gubbels GH. Growing buckwheat, Agriculture Canada Publication 1468. Agriculture Canada, Ottawa, 1978.

5. Dongol DMS. Buckwheat marketing and commercialization in Nepal. In: Research and Development on Buckwheat: An Important yet a 
Neglected Crop in Nepal (Bimba HP and BK Joshi, eds.) Proceedings of National workshop Kathmandu, Nepal. 2001; 13(14):28-38.

6. Farre I, Faci JM. Comparative response of maize (Zea mays L.) and sorghum (Sorghum biocolor L. Moench) to deficit irrigation in a Mediterranean environment. Agricultural Water Management. 2006; 83:135-143.

7. Ghosh PK, Das A, Ngachan SV, Saha R, Munda GC, Patel DP et al. In-situ soil moisture and nutrient conservation in north-eastern hill agriculture. Technical bulletin 68, ICAR Research Complex for NEH Region, Umiam, Meghalaya, 2009.

8. Gomez KA, Gomez AA. Statistical procedures for Agriculture Research. $2^{\text {nd }}$ edition. John Willey and Sons. New York, 1984.

9. Gubbels GH. Yield, seed weight, hull percentage and testa colour of buckwheat at two soil moisture regimes. Can. J. Plant Sci. 1978; 58:881-883.

10. Jackson ML. Soil Chemical Analysis. Prentice Hall Publication Pvt. Ltd., New Delhi, India, 1967, 452.

11. Joshi BD, Paroda RS. Buckwheat in India, National Bureau of Plant Genetic Resources Regional Station, Phagli, Shimla, India. 1991; 2:1-125.

12. Krotov AS. (Buckwheat) Izdatel stvo sel Skonozjajstvennij Literatury, Moscow-Leningrad, 1963.

13. Li H, Bian J, Liang $X$, Deng $X$, Shan F, Lin R. The effects of fertilization on botanic characteristic and yield of tartary buckwheat ( $F$. tataricum). Proceedings of the $9^{\text {th }}$ International Symposium on Buckwheat, prague, 2004, 524-528.

14. Noworolink K. Nitrogen fertilization efficiency of buckwheat grown at various soil conditions. The $6^{\text {th }}$ International symposium on buckwheat. Current Advances in Buckwheat Research, 1995, 601-604.

15. Patel SR, Thakur DS, Lal N. Yield and nutrient uptake of wheat (Triticum aestivum) varieties under different sowing dates. Journal of Agronomy. 1999; 44(4):733737.

16. Rana RS, Rana SS, Rana MC, Prasad R. Influence of row spacing and fertility levels on Tartary Buckwheat (Fagopyrum Tataricum Gaertn) under Sangla valley conditions of Himachal Pradesh. Himachal Journal of Agricultural Research. 2005; 31(1):3-7.

17. Saini AD, Dhaliwal VK, Phadnawis BN, Nanda R. Thermal and photoperiod effect on phase duration of four wheat varieties grown in different sowing date. Indian Journal of Agricultural Sciences. 1986; 56:646-656.

18. Snezana O, Zeljko D, Mico O, Snezana D. Effect of microbiological fertilizer and soil additive on yield of buckwheat (Fagopyrum esculentum Moench) under high altitude conditions. Ratar. Povrt. 2012; 49(3):302-306.

19. Sobhani MR, Rahmikhdoev G, Mazaheri D, Majidian M. Influence of different sowing date and planting pattern and $\mathrm{N}$ rate on Buckwheat yield and its quality. Australian J. Cro. Sci. 2014; 8(10):1402-1414.

20. Wang J, Kang S, Li F, Zhang F, Li Z, Zhang J. Effects of alternate partial root-zone irrigation on soil microorganism and maize growth. Plant and Soil. 2008; 302:45-52.

21. Yoon YH, Jang DC, Jeong JC. Effect of soil moisture condition on some growth characteristics related with landscape and yield of buckwheat. Proceedings of the $9^{\text {th }}$ International Symposium on Buckwheat, Prague, 2004, 465-469. 